As you can see, my enthusiasm for the place of popular music in an academic setting is high. That does not mean there are no pitfalls, including the very real problem of protecting the collection from theft. This is crucial when you are dealing with a non-research collection like ours with materials readily accessible and therefore stealable. CDs are especially vulnerable.

And we have had other problems, such as finding the funds to keep the project going. Unfortunately the Main Library is no longer able to allocate special grants or allow us to utilize non-music budget lines. Since the Music Library budget must continue to be earmarked for curriculum-related purchases, we have for the first time applied for grant money to purchase additional popular and local music materials. I am exploring other options as well and feel confident that we will be able to continue adding to the existing collection.

The popular music collection has indeed turned out to complement and not compete with the curriculum-oriented materials in our library. Knowing the limitations, being aware of the primary mission of the university, and remaining sensitive to the politics and economics of the situation makes integrating popular music into our collection feasible and rewarding.

So if you are planning to be in New Orleans this July for the ALA Annual Conference, take the St. Charles streetcar uptown (a tourist "must" in any case) and come visit us at the Loyola Music Library. You are welcome to use our collection, whether you're interested in Bach, the Boogie Kings or-better yet-both!

Editor's note: This article is based on a paper presented at the Annual Meeting of the Popular Culture Association in New Orleans, March 25, 1988.

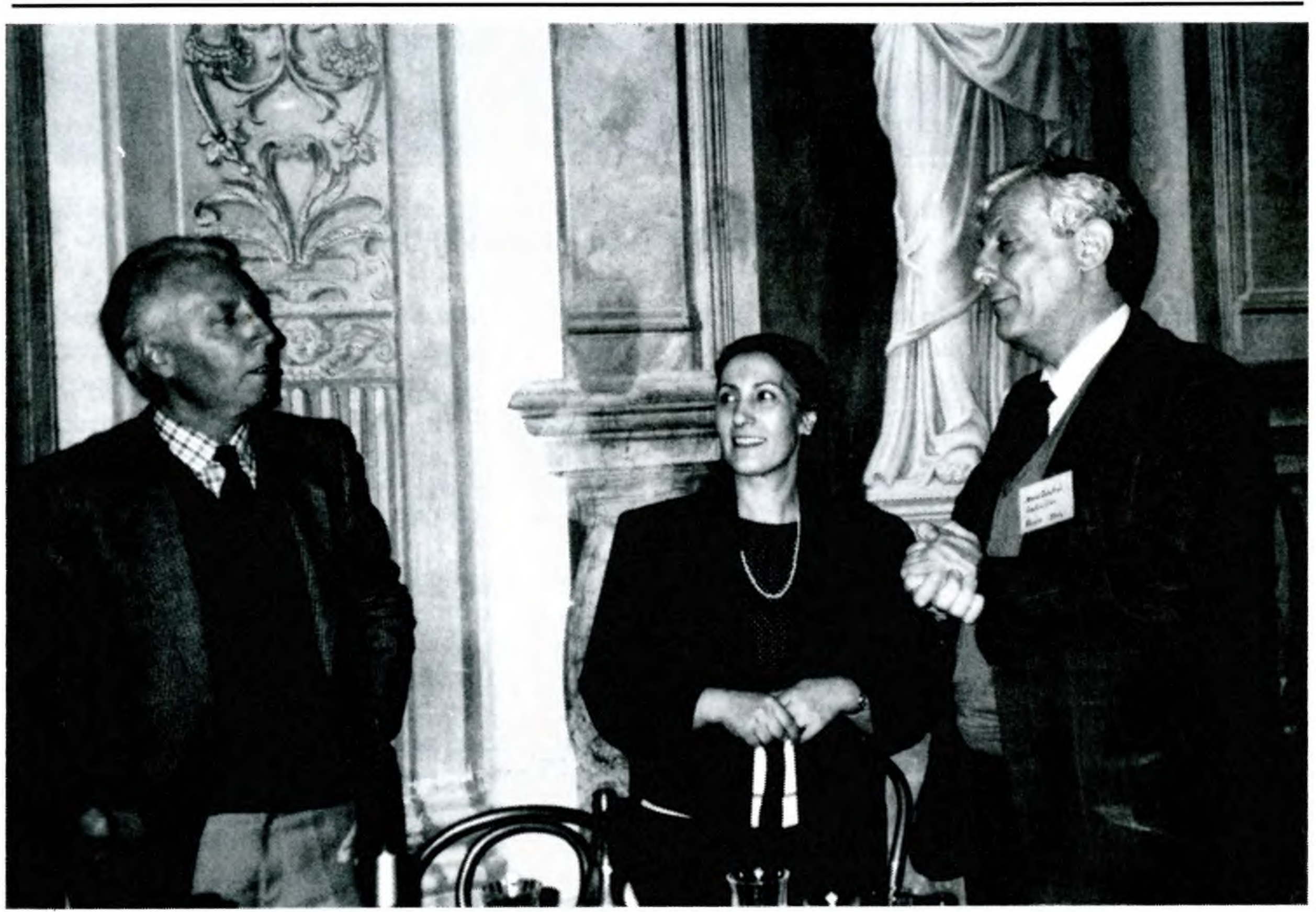

(l-r) Marcello Buzzonetti, Secretary, European University Institute, Fiesole, Italy; Assunta Pisani, Collection Development Librarian, Harvard University; and Mario Casalini Managing Director,

Casalini Libri, Fiesole.

Credit: Martha Brogan

\title{
WESS goes to Florence
}

To the second international conference of ACRL's Western European Specialists Section, held in Florence, Italy, on April 4-8, 1988, came 90 U.S. librarians to meet with 60 Western European librarians, publishers, and book distributors.
The aim of the conference, entitled "Shared Resources, Shared Responsibilities," was to enable these people to meet with each other and to discuss current collection development realities, trends and problems. One particular emphasis for Ameri- 


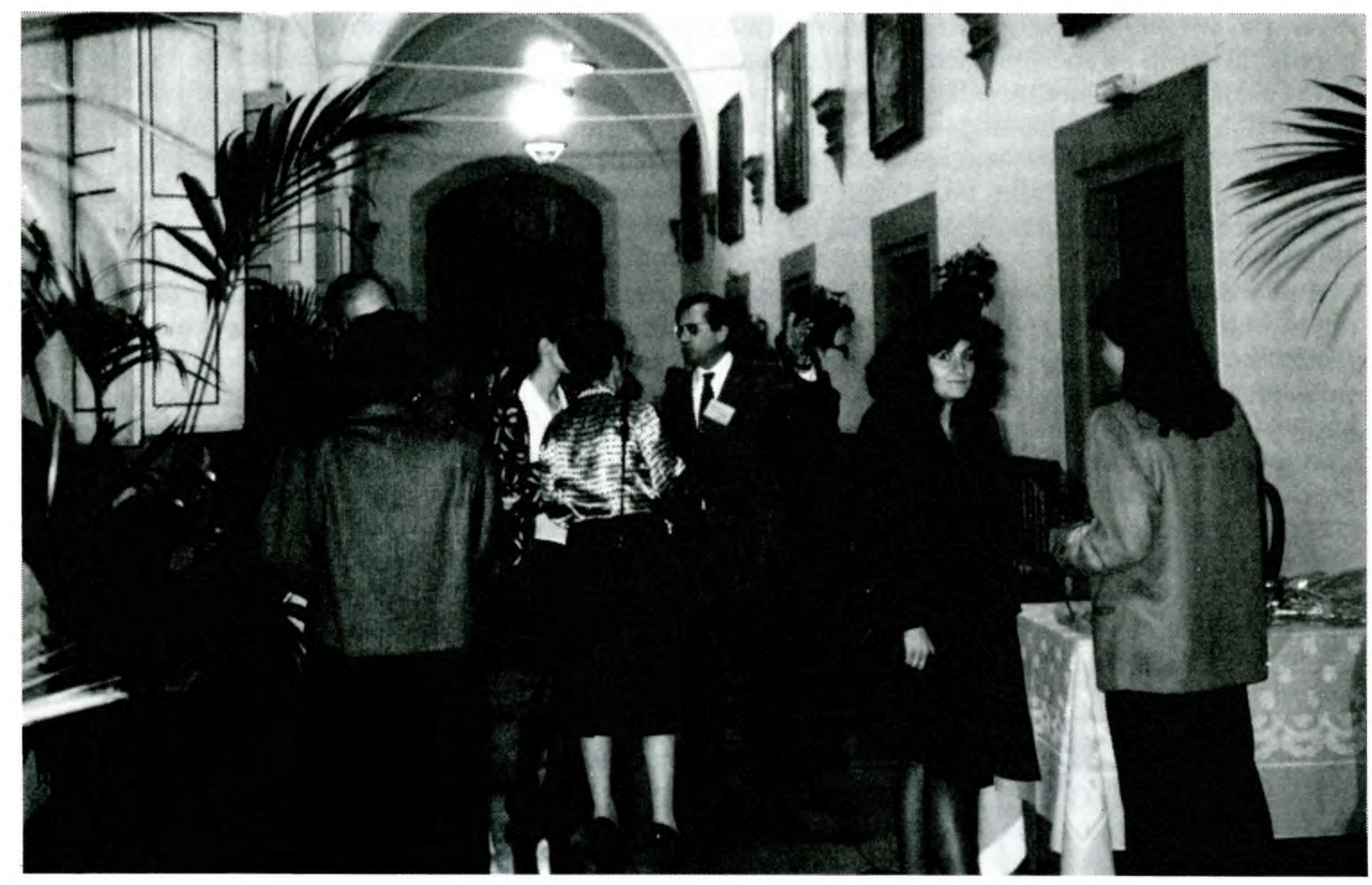

Reception, sponsored by Casalini Libri at the Villa di Mezzomonte outside Florence. Michael Albin (center), Head of Acquistions at the Library of Congress.

can librarians was on how to locate some of the more elusive European publications.

The opening session immediately brought to the fore a recurring conference theme-the difference in philosophy between European and American academic librarians. The Europeans see their primary function as curatorial and the Americans see theirs as delivery of information. Herbert R. Lothman, author and international correspondent of Publisher's Weekly, delivered a salvo against the Bibliothèque Nationale in Paris in recounting his difficulties in doing research there. The next day Le Roy Ladurie, administrateur generale of the Bibliothèque, responded sharply to his criticisms but did admit to the poor health of the Paris libraries. Implicit in some of his remarks was the thought that perhaps the expectations of American scholars were unrealistic in their demands for a level of service not contemplated or offered.

The conference provided 19 sessions packed with information; each 90-minute period included at least three short papers. Topics ranged widely from "Large Microform Collections" and "Databases and Online Communication" to "Local History and Regional Publishing" and "Women's Studies in Western Europe." One would have liked more time for discussion.

One of the most interesting sessions, "European National Libraries in Transition," revealed that the concept of a national library is surprisingly difficult to define. The French, according to Le Roy Ladurie, are now trying to disperse their central national library into a number of other locations around Paris, and to provide telecommunication with other natural resources as a supplement to their collections.

The Italians do not really have a national library, according to Anna Lenzuni of the Biblioteca Nazionale Centrale in Florence, but they have regional centers. The Biblioteca Nazionale serves as a central institution only for bibliography.

Several European countries, including Belgium, Switzerland, and Spain, in trying to deal with substantial ethnic and linguistic regionalism have opted for decentralization of library collections. These countries are trying for a better balance between conservation and communication, but in many the museum, not the library, is regarded as the center for information. All librarians emphasized severe financial constraints.

The crux of many library problems continues, as always, to be a question of finances-not enough government or institutional support of the library, rising costs of books and periodicals, and the cost of new technology. In another excellent session, "Databases and Online Communication I," Karen Hunter of Elsevier Science Publications observed that we are technically capable of doing much more with electronic delivery of information than library finances will allow, and that scholarly publishing in electronic form is not encouraging because the market is small, fragmented, and poorly funded. The PC revolution has created wants that cannot be fulfilled at present. Commercial vendors 
are interested in huge datafiles for many users; the only successful scholarly databases have been taxsupported.

Leslie Hume of the Research Libraries Group also spoke of the proliferation of very specialized scholarly databases and about the need for comprehensive sources or indexes to make these accessible. She sees a need for databases with an interdisciplinary focus, for more archival repositories in electronic form, and for more access to visual materials. She reiterated the need for institutional funding, since scholarly databases are not revenueproducing.

What emerged from these meetings was that European libraries are exploring the sharing of resources, mostly within their own boundaries, but that national libraries are contending with problems of increasing regional ethnic focus. It is clear that in Europe, as in the U.S., that new technology is forcing librarians to make hard choices. The Europeans are trying to make appropriate and financially possible selections of electronic technologies, but are finding difficulties with incompatible hardware and rapidly changing products.

Most Continental librarians continue to see their role as curatorial; however, they do not aim at completeness of collections as do American research librarians. In fact, the idea of a complete collection appears unrealistic to European librarians, as indicated by the discussion at the session on "The Conspectus as a Collection Management Tool for Western European Studies."

All in all this first overseas ACRL conference was both enlightening and stimulating. U.S. librarians found much to exchange with others from their own country as well as with the Europeans. As always, the informal exchanges were as valuable as the working sessions.

Florence was an ideal choice for a site, although perhaps too seductive a city for conferees. It took real strength of character to resist the lure of the museums, churches, and Renaissance streets in favor of meetings. And the hospitality (repasts and entertainment) arranged by Mario Casalini of Casalini Libri was superb - probably never again will a library conference offer such feasts in such elegant surroundings.-Claire Dudley, Science and Nonprint Editor, Choice, Middletown, Connecticut.

\section{RTSD preservation microfilming institute at Yale University}

For two and a half days, April 21-23, 1988, over 110 librarians and archivists met at Yale University for a program entitled "Preservation Microfilming: Planning \& Production," a regional institute sponsored by the ALA Resources and Technical Services Division's Reproduction of Library Materials Section. The Institute was a follow-up to their earlier institute, "Preservation Microfilming: Administrative Issues," held in March 1986. Both programs were planned in order to meet the training needs of libraries currently or prospectively involved in preservation microfilming. The recent institute was designed to provide practical information and training to those responsible for microfilming programs.

Following welcoming remarks by Yale University librarian Millicent Abell, Wesley Boomgaarden, preservation officer at the Ohio State University Libraries, spoke on the elements in the preservation microfilming process and their interconnections to the library's preservation activities and other operations, such as collection development and providing bibliographical control. Boomgaarden also discussed such "macro-issues" as the institutional planning process, cost control, technologies to consider, and the effect on the library users.

To ensure that microfilm will provide a permanent copy, libraries must meet many special stan- dards and specifications in the preparation, production, duplication, and storage of the microfilm. Myron B. Chace, head of the Special Services Section, Photoduplication Service, at the Library of Congress, reviewed many of the standards and specifications in the filming process, providing some insights into their development.

A key part of the Institute was four preparation workshops, each focusing on a different type of material: monographs, serials, newspapers, and manuscripts and archives. Each of the workshop leaders described key steps in the preparation process: searching available records to determine the existence of other microform or hard copies; the physical examination and preparation of material; the physical preparation of the items to be filmed, including collation, targeting, and reel programming; film inspection and other post-filming procedures. The workshop leaders for these sessions were Sherry Byrne, preservation librarian, the University of Chicago Library (Monographs); Tamara Swora, assistant preservation microfilming officer, Preservation Microfilming Office, the Library of Congress (Serials); Ann Swartzell, associate librarian (Conservation), New York State Library (Newspapers); and Vanessa Piala, head of preservation services, Smithsonian Institution Libraries (Archives and Manuscripts).

Participants had the opportunity to see such 